\title{
A STUDY OF THE RELATIONSHIP BETWEEN BANKING SECTOR'S PROFITABILITY AND INTEREST RATES ON DEPOSITS USING JOHANSEN COINTEGRATION AND GRANGER CAUSALITY TEST
}

\section{DOI: 10.17261/Pressacademia.201519779}

\section{Osman Uluyol', Samiye Ekim²}

1Adıyaman Üniversitesi, ouluyol@adiyaman.edu.tr

${ }^{2}$ Adıyaman Üniversitesi, sekim@adiyaman.edu.tr

Keywords
Interest Rates on
Deposits, Banking
Profitabilty,
Granger Causality Test,
Johansen Cointegration
Test.

Test.

Jel Classification

C58, E40, G29

\begin{abstract}
The profitability of banking sector has a critical importance in terms of this sector. There are various determiners of the profitability in banking sector. In this research the relationship between interest rates on deposits that is one of determiners of profitability and profitability in the banking sector is being studied and the effects of change in interest rates in deposits on the profitability in banking sector researched. The relationship between Return on Assets (ROA) and Return on Equity (ROE) which are the basic profitability indicators in banking sector is being tried to be detected using quarterly data for the period 2003Q1-2013Q4. Additionally the effects of 2008 global finance crisis is being tried to be reflected with the help of dummy variable. 3 public, 11 private equity and 18 foreign capitalized banks were included in the scope of the research. As a result of this research in which Johansen Cointegration and Granger Causality Tests were used has been found a long term relationship between variables and one way causality from the profitability indicators to interest rates.
\end{abstract}

\section{BANKACILIK SEKTÖRÜNÜN KARLILIĞI ILE MEVDUAT FAIZ ORANLARI ARASINDAKi iLIŞKININ JOHANSEN EŞBÜTÜNLEŞME VE GRANGER NEDENSELLIK TESTI ILE ARAŞTIRILMASI ${ }^{1}$}

\section{Anahtar Kelimeler \\ Mevduat Faiz Oranları, Bankacılık Karlılığı, Granger Nedensellik Testi, Johansen Eşbütünleşme Testi.}

JEL Sınıflandırması C58, E40, G29

\section{ÖZET}

Bankacılık sektörünün karlılığı sektörün geleceği açısından kritik önem taşımaktadır. Bankacılıkta karlıığın çeşitli belirleyicileri vardır. Bu çalışmada karlılığın belirleyicilerinden mevduat faiz oranları ile bankaların karlılığı arasındaki ilişki ele alınmakta ve mevduat faiz oranlarındaki değişimin bankacılık karlılığı üzerindeki etkisi araştırılmaktadır. Türkiye'deki bankacılık sektörünün temel karlılık göstergeleri olan aktif karlılığı ve özsermaye karlılığı rasyoları ile mevduat faiz oranları arasındaki ilişki çeyrek dönem verileri kullanılarak 2003:1-2013:4 dönemi için tespit edilmeye çalışıımıştır. Ayrıca 2008 küresel finans krizinin etkileri de kukla değişken yardımıyla yansıtılmaya çalışılmıştır. Araştırmaya 3 kamu sermayeli, 11 özel sermayeli ve 18 yabancı sermayeli banka dahil edilmiştir. Johansen Eşbütünleşme ve Granger Nedensellik Testi'nin kullanıldığı çalışmada değişkenler arasında uzun dönemli ilişki ve karlılık değişkenlerinden, mevduat faiz oranlarına doğru tek yönlü bir nedensellik tespit edilmiştir.

\footnotetext{
${ }^{1}$ Bu çalışma, 2014 yılında gerçekleştirilen 18. Finans Sempozyumu'nda sunulan bildirinin gözden geçirilmiş halidir.
} 


\section{GíRiş}

Bir ekonomide finansal sistemin iyi işlemesi ekonomik gelişmeye önemli katkı sağlar. Türkiye'de finans sektörünün omurgasını bankacılık sektörü oluşturmaktadır. Bunun nedeni tasarrufların özellikle bankalar kanalı ile toplanması ve bu kuruluşlar tarafından ihtiyaç duyulan alanlara tahsis edilmesidir. "Ticari bankalar karlarını maksimize etmeye ve piyasa paylarını genişletmeye çalışan firmalar olarak nitelendirilebilmeleri nedeniyle karlılıklarını etkileyen faktörlerin belirlenmesi, gerek banka düzeyinde gerekse makroekonomik düzeyde politika tespitleri açısından önem taşımaktadır". (Gündoğdu ve Aksu, 2011: 243). "Bankaların temel ekonomik işlevleri mali aracılıktır. Bankacılık sektörünün mali işlevleri sonucu ekonomide ödünç verilebilir fon arzı ve fon talebi artar, bunun sonucunda mali piyasaların hacmi genişler, milli gelir ve istihdam artar. Bankaların makroekonomik açıdan önemli bir işlevi de, mali sisteme çekilen fonların ekonomik kalkınmaya en yüksek katkıyı sağlayacak olan kişilere ve sektörlere yönlendirilmesidir" (Saldanlı, 2013: 40). Bankacılık sisteminin etkinliği daha çok kredi verme faiz oranı ve mevduat faiz oranı arasındaki marjın incelenmesi ile anlaşılabilir. Faiz marjlarının yüksek olması bankacılık sisteminin yeterince etkin olmaması ya da rekabetçi olmayan piyasa koşulları ile açıklanabilir. (Taşkın, 2011: 289).

Türk bankacılık sektörü yakın geçmişte ciddi bir kriz yaşamış ve bu krizin sonucunda birçok banka piyasadan silinmiştir. "Kasım 2000 ve Şubat 2001 tarihlerinde Türk ekonomisinde yaşanan krizler, bankacılık sektörünü olumsuz yönde etkilemiştir. Türk bankacılık sektörü Kasım 2000 krizi ile faiz riskine, Şubat 2001 krizi ile de döviz kuru riskine maruz kalmış ve bilançolarında büyük zararlar oluşmuştur. Yaşanan şoklar sonucunda büyük problemler yaşayan bankacılık sektörünün daha sağlıklı hale getirilmesi ve sorunların kalıcı olarak çözümlenmesi amacıyla Mayıs 2001 tarihinde Bankacılık sektörü yeniden yapılandırma programı uygulamaya konulmuştur (Saldanlı, 2013: 41). 2000-2001 kriz döneminde bankacılık sektöründe yapılan düzenlemeler ve iyileştirmeler sayesinde, bankacılık sektörü küresel finans krizinin daraltıcı etkilerini daha kolay atlatabilmiştir (Kibritçi Artar ve Atılgan Sarıdoğan, 2012: 7).

Bu çalışmada mevduat faiz oranları ile bankaların karlıığı arasındaki ilişki, Johansen Eşbütünleşme ve Granger Nedensellik Testi ile araştırılmaktadır. Bankaların karlılığı, özsermaye karlılığı (Net Kar/Özsermaye) ve aktif karlılığı (Net Kar/Aktifler) olarak iki şekilde alınmıştır.

Araştırma sonucunda faiz politikaları ile ilgili öneriler geliştirilmesi de amaçlanmaktadır. Konu ile ilgili literatüre bakıldığında bankacılık karlılığı ile çeşitli makro ekonomik değişkenler arasında ilişkileri araştıran çeşitli yayınların yapıldığı görülmektedir. Ancak faiz oranları ve bankacılık karlılığı arasında ilişkiyi doğrudan araştıran bir çalışmaya rastlanmamıştır. Bu nedenle bu çalışma alanına katkıda bulunmaya çalışılacaktır.

\subsection{Bankacılıkta Performans Kriterleri}

Türk bankacılık sektörünün temel gelirleri olan net faiz gelirlerinin toplam gelirler içindeki payı kriz yılları olan 1994 ve 2001 yılları hariç tutulduğunda ortalama yüzde 80 civarındayken, 2002 yılından sonra yüzde 60'lar seviyesine gerilemiş (Atasoy, 2007: 19) ve 
2012 yıl sonu itibariyle toplam gelirlerin \%67,44'ünü oluşturmuştur (http://www.turcomoney.com/turk-bankacilik-sektoru.html). Bankaların gelirleri esas itibariyle faiz gelirleri ve faiz dışı gelirlerdir. Dolayısıyla faiz oranları da faiz gelirlerini etkilemesi nedeniyle banka karlılığının belirlenmesinde önemli etkiye sahiptir. Ancak arz ve talep şartlarına göre faiz oranları değişebilmektedir.

Bir başka görüşe göre de bankaların performanslarının ekonomik yönü ile değerlendirilmesi durumunda farklı finansal performans kriterleri kullanılabilmektedir. Bu kriterler genel olarak, karlılık (sermaye yeterliliği, aktif kalitesi, likidite, gelir-gider yapısı, grup ve sektör payı) ve risk (likidite, kredi faiz oranı, sermaye) kriterleridir (Albayrak ve Erkut, 2005: 51-52).

Bir bankanın elde ettiği vergi sonrası net kar değeri, söz konusu bankanın performansını ölçebilmek için başlı başına bir ölçüt olmasına rağmen banka büyüklüğünü içermediği için diğer bankalarla karşılaştırma yapmak açısından yeterli görülmemektedir (Gündoğdu ve Aksu, 2011: 244). Aktif büyüklüğünü de kapsayan en önemli performans göstergesi aktif karlılık oranıdır. Bu oran banka varlıklarının kar oluşturabilmek amacıyla hangi etkinlikte kullanıldığını göstermesi bakımından banka yönetiminin etkinlik kriteri olarak da kabul edilmektedir.

Banka hissedarlarının daha çok bankaya konulan sermayenin hangi karlılık düzeyinde çalıştığını görmeleri açısından temel bir karlılık kriteri olarak özsermaye karlılı̆̆ı oranı kullanılmaktadır (Gündoğdu ve Aksu, 2011: 244). Bir bankanın performansını ölçmede kullanılan net faiz marjı kriteri ise bir birim varlık için elde edilen faiz gelirini ifade etmekte olup bankaların aktif ve pasif yönetimindeki başarılarının bir göstergesi olarak kabul edilebilmektedir (Gündoğdu ve Aksu, 2011: 245).

Türkiye'de parasal aktarım mekanizmalarından banka kredi kanalı ile hisse senedi kanalının çalışmadığı, faiz kanalı ile döviz kuru kanalının çalışmaması, Türkiye'de hisse senedi piyasasının yeterince derinlik kazanmadığını göstermektedir. Finansal sistem geliştikçe, derinleştikçe ve çeşitlendikçe bu kanallar daha etkin çalışmaktadır. Türkiye'de parasal aktarım kanalları içinde geleneksel faiz oranı kanalının paranın reel ekonomiye aktarımında en etkili çalışan kanal olduğu belirtilmektedir (Çoban ve Şahin, 2011: 340).

\subsection{Karlılık}

Karlılık, bankaların sektördeki rekabet pozisyonunun belirleyicilerini ve yönetim kalitesini ortaya koyar (Greuning ve Bratanovic, 2000: 83). Bankaların karlılığını etkileyen faktörlerin belirlenmesi, bankaların uygulayacağı politikanın tespiti için önemlidir. Aktiflerden elde edilen gelirler ve pasiflerin maliyeti ve yasal yükümlülükler arasındaki fark olarak tanımlanan net kar, bir bankanın faaliyetlerine devam edebilmesi ve en azından bulunduğu düzeyi koruyabilmesi açısından fevkalade önemlidir. "Bir bankanın karlılık düzeyini etkileyen çeşitli faktörler bulunmaktadır. Örneğin; bankanın risk alma politikası ne olursa olsun, pazarın yapısı uzun vadede banka karlılıklarını etkileyen bir unsur olmaktadır. Temel olarak bir bankanın karlıığını etkileyen faktörleri, kontrol edilebilir faktörler ve kontrol edilemeyen faktörler adı altında iki grupta incelemek mümkündür. 
Bu bağlamda, bir bankanın faaliyet alanı, net kar marjı, ücret ve komisyonlar, mevduat ve kredi kalitesi, maliyet kontrolü (işlemsel, şube, personel) gibi faktörler kontrol edilebilen faktörler arasında yer alır. Buna karşın genel ekonomik koşullar, faiz oranları ve sektördeki rekabetin niteliği gibi faktörler ise kontrol edilemeyen faktörlerdir" (Sarıtaş ve Saray, 2012:29). Bankacılığın başlıca karlılık ölçütlerinin, bankaların aktif karlılığı, net faiz marjı ve özsermaye karlılığı olduğu görülmektedir. Bahsedilen karlılık ölçütlerini açıklayan değişkenler ise; bankalar tarafından kontrol edilebilen mikro değişkenler, genel çevre ve ekonomik koşulların yönlendirdiği makro değişkenler ve yerleşik finansal sistemin özelliklerini temsil eden finansal yapı değişkenleri olduğu belirtilmektedir (Çerçi, 2011: 1).

Bankaların karlılığını etkileyen çeşitli değişkenler arasında faiz oranlarının bu konuda en önemli değişkenlerden biri olduğu düşünülmektedir. Faiz bankaların temel işlevi içinde maliyet ve getiriyi ifade etmesi sebebiyle, bankacılık sektörünün karlılığı için önemli bir değişkendir. Kısa ve uzun vadeli faizlerin etkilerine doğrudan muhatap olan bankaların yapısal faiz oranı riski ve piyasa riski kapsamındaki faiz oranı riski, değişen piyasa koşullarında karlılık için tehditler ve fırsatlar sunabilmektedir(Tarkoçin ve Yekeler, 2010: 5). Faiz oranlarındaki değişim bankaların maliyetlerini ve getiri oranlarını doğrudan etkilemektedir. Bununla beraber, kaynak yapısı genelde tasarruf, yani borçlanma imkanlarıyla ilintiliyken, plasman yapısında iradi politikalar daha geçerlidir. Kaynak sağlayıcılar ve piyasa dinamikleri öncelikli olarak faiz maliyetlerine etki ederken, ikincil olarak bankaların ürün fiyatları niteliğindeki plasman faiz oranları aracılığıyla faiz gelirlerine etki etmektedir (Tarkoçin ve Yekeler, 2010: 6).

\subsection{Faiz Politikası}

Merkez bankaları bankalara uyguladıkları faizlerde yaptıkları düzenlemelerle piyasa faizlerini etkilemek suretiyle parasal işlemleri ve buna bağlı olarak da piyasaları ve ekonomiyi etkileyebilirler. Bu amaçla uygulanan politikalara faiz politikası denir. Örneğin; Merkez Bankasının haftalık repo faizini yüzde $4,5^{\prime}$ dan $5,5^{\prime}$ e ya da gecelik faizi yüzde 7,75'den 8,50'ye yükseltmesi halinde bu fonlardan yararlanan bankaların ortalama maliyetleri yükseleceği için kredi faizleri de yükselecek ve kredi kullanımında bir daralma olacaktır (Eğilmez, 2013: 1).

Faiz politikası uygulandığında merkez bankaları para arzının kontrolünü bırakırlar. Kontrol etmek istedikleri faiz oranında para arzının ne olacağı piyasadaki para talebine göre belirlenir. Para talebindeki oynaklık merkez bankalarının faizi kontrol ettiği ortamda para arzında oynaklığa neden olur. Aynı şekilde merkez bankalarının para arzını kontrol ettiği durumlarda, para talebindeki oynaklık faizlerde oynaklığa neden olur. (http://www.ekodialog.com/Konular/faiz_politikasi.html).

Para piyasasında oluşan faiz oranının önemli ekonomik kararları etkileyen bir değişken olması nedeniyle merkez bankalarını faiz politikasını bir araç olarak kullanmaktadır. Bunun sonucunda mevduat ve kredi faizleri bundan etkilenmekte ve bunun sonuçları bankaların karııı̆ını da etkilemektedir. 


\section{LITERATÜR INCELEMESi}

Araştırma konusu ile ilgili literatüre bakıldığında bankacılık alanında çok sayıda araştırma yapıldığı görülmektedir. Bu araştırmaların konuları genellikle makro ekonomik faktörler ile bankacılık karlılı̆ı, bankacılıkta karlılığın belirleyicileri gibi konularda yoğunlaşmaktadır. Araştırma konumuz olan mevduat faiz oranları ile bankacılık karlılığı arasındaki ilişkiyi araştıran bir çalışmaya rastlanmamıştır. Sadece diğer faktörlerin arasında faizlerin etkisini de ele alan çalışmalar mevcuttur. Araştırma konumuz ile ilgili olan araştırmaların özeti burada verilmektedir.

Molyneux ve Thornton (1992), 1986-1989 dönemi itibariyle 18 Avrupa ülkesi için özel sektör bankaları, kooperatif bankaları ve tüm kamu sektörü kredi kuruluşlarını inceleme konusu yaparak banka karlıı̆ı̆ın belirleyicileri üzerinde çalışmışlar ve ülkelerin faiz oranı düzeyi, banka konsantrasyonu ve hükümetin pay sahipliği ile hisse senedi getirisi arasında pozitif ilişki saptamışlardır. Yazarlar araştırmış oldukları her ülkede bankaların özsermaye karlılığı ile ülkedeki faiz oranları arasında anlamlı pozitif ilişki olduğunu bulmuşlardır.

Kaya (2002), Türk bankacılık sektöründe karlılığın belirleyicilerini incelemiştir. Çalışmada hem mikro hem de makro belirleyiciler üzerinde durulmuş, sonuç olarak mikro belirleyiciler olan özsermaye, likidite, personel harcamaları ve mevduatlar, makro belirleyiciler olarak da enflasyon ve konsolide bütçe açığı değişkenleri anlamlı çıkmıştır.

Jiang, vd. (2003), yaptıkları araştırmada 1992-2002 yılları arasında Hong Kong'daki 14 bankanın verileri ve makro ekonomik değişkenler kullanarak karlılığın belirleyicilerini araştırmışlardır. Makro değişkenler arasında enflasyon, reel faiz oranı ve büyüme oranı ile karlılık arasında pozitif bir ilişki çıkmıştır. Büyük bankaların ve yerli bankaların karlılık performanslarının daha düşük olduğu çalışmanın diğer bulguları arasındadır.

Guru vd. (2005)'nin bulgularına göre karlılık ile yüksek faiz oranları arasında negatif yönlü bir ilişki bulunurken enflasyonun etkisi pozitif olarak bulunmuştur.

Kaya ve Doğan (2005), bankacılık sisteminin enflasyonun düştüğü 2002 sonunda, etkinliğini veri zarflama analizi kullanarak incelemiş, bu süreçte bankacılık sektörünün etkinliğinde olumlu bir eğilim gözlendiğini ortaya koymuşlardır. Yazarlara göre makroekonomik ortamdaki olumlu gelişmelere ve faiz oranlarında yaşanan hızlı gerilemeye bağlı olarak bankaların aracılık işlevinin daha etkin bir şekilde yerine getirdiklerini ortaya koymuşlardır.

Atasoy (2007), 1990-2005 dönemi itibariyle bankalara özgü, endüstriye ilişkin ve makroekonomik değişkenlerin, Türk Ticaret Bankalarının net faiz marjı ile aktif karlılıkları üzerindeki etkilerini araştırmış ve bankalara özgü değişkenler ile makroekonomiye ilişkin değişkenlerin yanı sıra finansal yapıya ilişkin göstergelerin de bankaların karlılık performansını etkilediği, büyüme oranı ve bankacılık sektöründe konsantrasyonun arttığı dönemlerde net faiz marjının daraldığı sonuçlarına ulaşıımıştır. 
Dietrich ve Wanzenried (2010), İşviçre'deki 372 banka üzerinde yaptığı çalışmada bankacılık karlılı̆ını belirleyen başlıca değişkenler olarak fonlama maliyetleri (mevduat faizleri), toplam özsermaye oranı, maliyet (gelir oranı, kredi riski, toplam mevduat / toplam varlık oranı, operasyonel verimlilik, toplam kredilerin toplam varlıklara oranı, reel GSYiH büyümesi gibi değişkenlerin banka karlılığı üzerinde oldukça etkili olduğu sonucuna ulaşmışlardır.

Uludağ ve Gökmen (2010), çalışmalarında enflasyon ve GSYiH büyüme oranı ile banka karlılığı arasındaki ilişkileri incelemişler ve GSYiH büyüme oranı ile banka karlılığı arasında pozitif ve istatistiki olarak anlamlı ilişki bulmuşlardır. Aynı çalışmada enflasyon ile banka karlılığı arasındaki ilişki de incelenmiş sonuç olarak sadece özel bankaların enflasyonun yüksek olduğu dönemlerde de karlılıklarını artırma eğiliminde oldukları sonucuna ulaşmışlardır. Adı geçen çalışmada diğer bankalarda enflasyon oranı ile banka karlılı̆̆ı arasında istatistiksel olarak anlamlı bir ilişki tespit edilememiştir.

Tarkoçin ve Yekeler (2010) araştırmalarında faiz oranlarının 2002-2010 dönemi için bankacılık sektörü üzerindeki etkilerini araştırmışlardır. Bankacılıkta temel politika alanları faiz marjı, uzun ya da kısa vadeli plasman tercihi ve faiz dışı gelir gider dengesi olarak tanımlamıştır. Bankaların plasmanda vade tercihi politika alanının giderek daralacağı, faiz marjı politika alanı kapsamında bilgi asimetrisine dayalı göreceli yüksek faiz marjı oluşturan ürünler ile Kredili Mevduat Hesabı ve kredi kartı gibi gecikmeye dayalı yüksek faizli ürün getirilerine ya da DCD (dual currency deposit) gibi düşük maliyetli ürünlere yöneleceği, faiz dışı gelir gider dengesi politika alanının daha etkin kullanılacağı örneklerin yaşanacağı düşünülmektedir. Özetle düşük faiz ve marjların söz konusu olabileceği önümüzdeki dönemlerde bankaların istikrarlı bir karlılık ve büyüme için üzerinde durması gerekeceği hususlar tespit edilmeye çalışılmıştır.

Taşkın (2011) tarafından yapılan araştırmada ticari bankaların performansını etkileyen içsel faktörlerin belirlenmesi amaçlanmış, sonuç olarak bankacılık performansının daha çok mikro değişkenlerden etkilendiği, makro ekonomik değişkenlerin (faktörlerin) anlamlı düzeyde bir etkisinin olmadığı ortaya çıkmıştır. Faiz oranlarındaki değişim, enflasyon ya da gayrisafi yurt içi hasıladaki değişimin banka performansına istatistiksel olarak anlamlı bir etkisinin bulunmadığı sonucu elde edilmiştir.

Gündoğdu ve Aksu (2011) çalışmalarında 1994-2008 dönemi itibariyle Türkiye'de mevduat bankalarında karlılık ve karlıığın makro ekonomik belirleyicileri olarak genel kabul gören reel faiz, fiyatlar genel düzeyi, bütçe açı̆̆ı ve sanayi üretim endeksi arasındaki ilişkiyi araştırmışlar ve sonuç olarak reel faiz oranlarının uzun dönemde; aktif karlılığı üzerindeki etkisi pozitif, sermaye karlılığı üzerindeki etkisi ise negatif bulunmuş, parametreler istatistiki olarak anlamlı çıkmıştır. Ancak kısa dönemde aktif karlılığı ve sermaye karlılı̆̆ üzerindeki net etkisi pozitif yönlü ve istatistiki olarak anlamlı çıkmıştır. Dolayısıyla pozitif reel faiz politikaları uygulamasının kısa dönemde banka karlılıkları üzerine olumlu etki yaptığı gözlenebilmektedir. 
İşcan ve Oransay (2011), araştırmalarında Türkiye'de banka karlılıklarının banka özellikli, sektör özellikli ve makro ekonomik belirleyicilerini ortaya koymayı amaçlamışlardır. Araştırmalarının sonucunda karlılığı etkileyen belirleyicilerin değiştiğini, özellikle karlılı̆ı belirleyen değişkenler arasında kredilerin artmasının ve özsermayesi yüksek olan bankaların fonlama maliyetlerinin düşük olması nedeniyle karlılığın pozitif etkilendiği sonucuna ulaşmışlardır. Dolayısıyla fonlama maliyetlerinin (mevduat faizleri) düşmesi karlılığa olumlu etki yapmıştır.

\section{VERI VE YÖNTEM}

Çalışmada çeyrek dönemler itibariyle 2003:1 - 2013:4 arasında Türkiye'de bankacılık sektörünün karlılık durumu ile mevduat faiz oranları arasındaki ilişki dönemdeki yaşanan 2008 krizini de göz önüne alınarak araştırılmaktadır. Bankacılık sektöründe faaliyette bulunan mevduat bankalarının karlılık durumunu gösteren aktif karlılığı ve özsermaye karlılığı bağımlı değişkenler olarak; mevduat faiz oranları da bağımsız değişken olarak kullanılmış, iki ayrı analiz olarak uygulanıp, karşılaştırılmıştır. Türkiye Bankalar Birliği verilerine göre Türkiye'de bankacılık sektöründeki 46 bankanın 32'si mevduat bankası olmakla birlikte; bunların 3 tanesi kamusal sermayeli, 11 tanesi özel sermayeli ve 18 tanesi de yabancı sermayeli bankadır. Değişkenler arasındaki ilişkiyi araştırmak amacıyla, serilerin durağanlığının tespit edilmesinde Genişletilmiş Dickey Fuller Testi, değişkenler arasında uzun dönemli ilişkinin tespit edilmesinde Johansen Eşbütünleşme Testi, değişkenler için en uygun gecikme uzunluğunun belirlenmesinde VAR (Vektör Otoregresif Model;) Analizi, değişkenler arasındaki nedenselliğin ve yönünün bulunmasında Granger Nedensellik Testi kullanılmıştır. Analizlerde Eviews 7.1 paket programı kullanılmıştır. Değişkenlerin tanımlamaları aşağıdaki gibidir:

Tablo 1: Kullanılan değişkenler

\begin{tabular}{|c|l|l|}
\hline \multicolumn{2}{|c|}{ Değişkenler* } & Tanımlama \\
\hline 1. & AK & Aktif Karlılığı, Net Kar(Zarar)/ Toplam Aktifler \\
\hline 2. & OK & Özsermaye Karlıı̆ı, Net Kar(Zarar)/ Özsermaye \\
\hline 3. & MFO & Mevduat Faiz Oranı \\
\hline 4. & d1** & 2008 Krizini Temsil Eden Kukla Değişken \\
\hline
\end{tabular}

*Değişkenlerden 1 ve 2, Türkiye Bankalar Birliği'nden, 3 de Türkiye Cumhuriyet Merkez Bankası'nın elektronik veri dağıtım sisteminden alınmıştır ${ }^{* *}$ Analiz döneminin 2008 krizini de kapsaması nedeniyle; kriz, kukla değişken yardımıyla çalışmaya dahil edilmiştir. 2008 yılının son çeyreği düşünülerek kukla değişken oluşturulmuş, kriz öncesi 0 , kriz dönemi ve sonrası 1 olarak veri girişi yapılmıştır.

Mevduat faiz oranları, aktif karlılığı ve özsermaye karlılığı serilerinin zaman grafikleri Şekil 1 'de gösterildiği gibidir: 
Şekil 1: Değişkenlerin 2003 - 2013 Dönemi Zaman Grafikleri

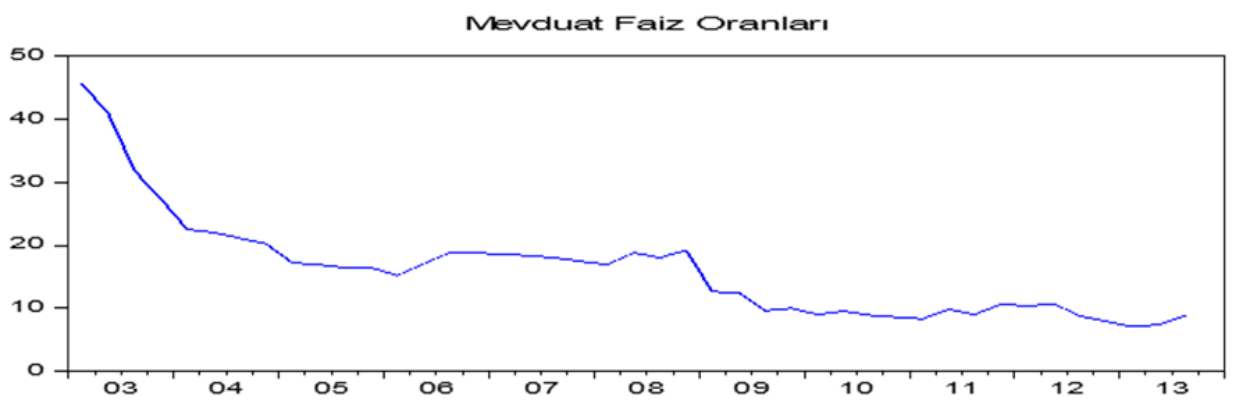

Özsermaye Karlilğı

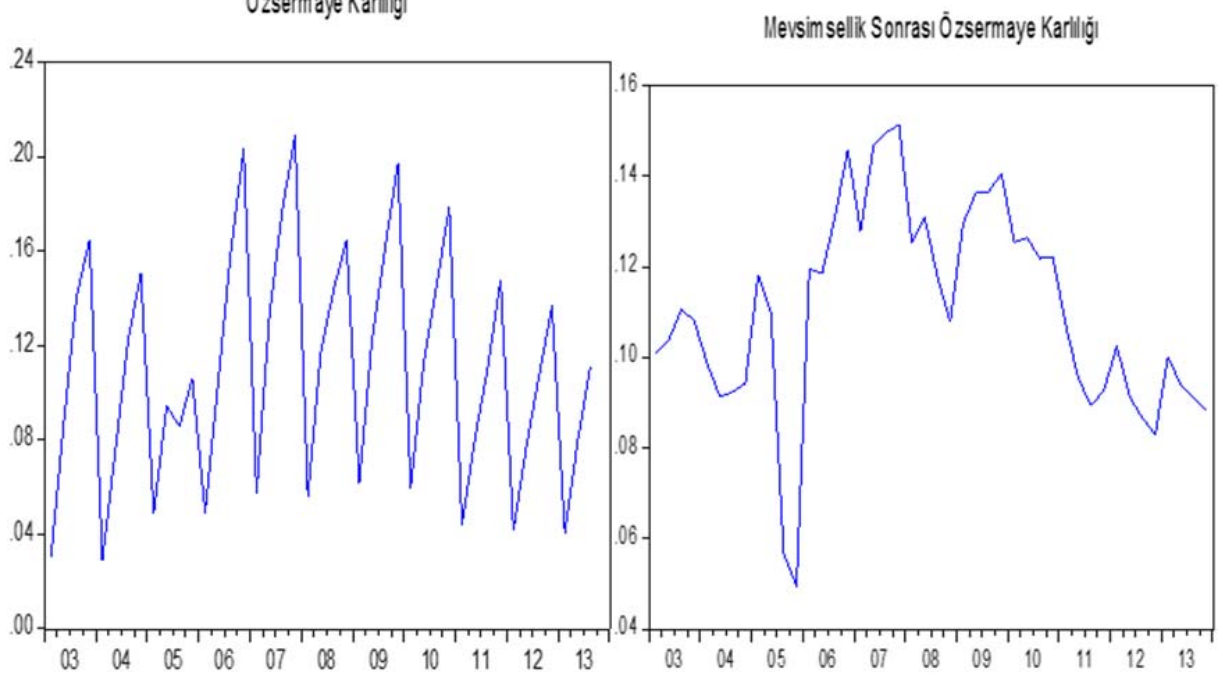

Akfif Karilliğ

Mevsimsellik Sonrası Akff Karlliğ

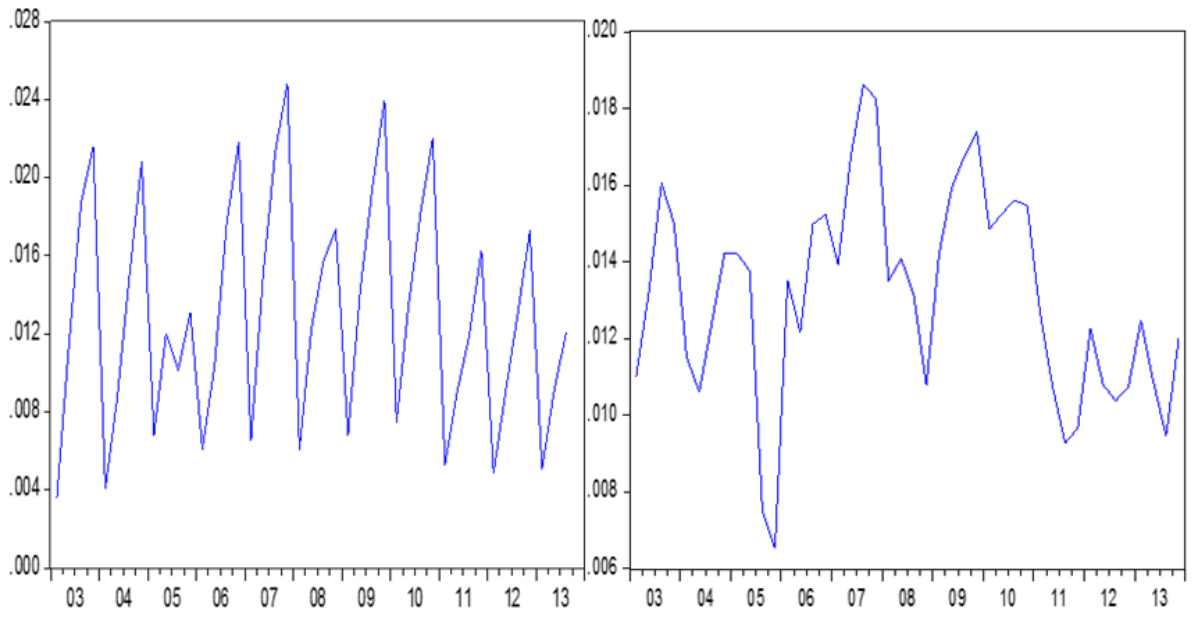

65 
Şekil 1.'deki değişkenlerin grafiklerinden de anlaşılacağı gibi aktif karlılığı ve özsermaye karlılığı değişkenlerimiz mevsimsellik içermektedir. Serilere ait soldaki grafiklerde mevsimsellik var iken, sağdaki grafiklerde seriler mevsimsellikten arındırılmıştır. Mevsimsellik sorunu düzeltildikten sonra yeni seriler ile analize devam edilmiştir.

\subsection{Birim Kök Testi}

Durağan serilerde; seri uzun dönemde, dalgalanmalar olsa bile aynı ortalamayı muhafaza eder. Zamana bağlı olarak değişmeyen bir sonlu varyansa sahiptir. Gecikme zamanı uzadıkça, korelogram gittikçe sıfıra yaklaşır ve sıfır olur. Durağan olmayan serilerde ise; serinin uzun sürede döneceği bir ortalama değer bulunmamaktadır. Zaman sonsuza yaklaştığında, varyans zamana bağlı olduğundan o da sonsuza yaklaşır (Kutlar, 2005:308).

Durağan olmayan seriler birim kök içerirler. Serilerin regresyon analizine tabi tutulabilmesi için birim kök testleri ile durağanlığının test edilmesi, durağan değilse durağanlaştırılması gerekir (Koşan, 2009:42).

Bankacılık sektörünün karlılık durumu ile mevduat faiz oranları değişkeni arasındaki uzun dönemli ilişkinin tespit edilmesi için, öncelikle bu değişkenlerin de durağanlık özelliklerinin sınanması gerekir. Serilerin durağanlıkları incelenirken, üç farklı durum söz konusudur:

1. İki değişkenin de tümleşme dereceleri aynı ise, eşbütünleşme analizinin kullanılması gerektiğinden sonraki adıma geçilir.

2. iki değişkenin tümleşme dereceleri farklı ise, iki değişkenin eşbütünleşik olmadığı sonucuna ulaşılır.

3. İki değişken de durağan yani $I(0)$ ise, test süreci durdurulabilir. Çünkü her iki değişken de durağan olduğu için geleneksel ekonometrik yaklaşım kullanılır.

Birim kök sınama hipotezleri şu şekilde kurulur:

$\mathrm{H}_{0}=$ Seri birim kök içermektedir. (Durağan değildir.)

$\mathrm{H}_{1}=$ Seri birim kök içermemektedir. (Durağandır.)

Serilerin birim kök testleri sonuçlarına bakıldığında değişkenlerin hepsi ADF değeri kritik değerden büyük olduğu için kendi düzeyinde durağan değildir. Serilerin olasılık değerleri de 0,05 den büyüktür. Serilerin hepsi birim kök içermektedir. ADF testinin sağlıklı sonuç vermesi, tahmin edilen modelde otokorelasyonun olmaması koşuluna bağlı olduğu için gecikme uzunluğunun doğru tespiti önemlidir. Bu amaçla genellikle Akaike Bilgi Kriteri (AIC) ve Schwarz Bilgi kriteri (SC) kullanılmaktadır.

Tablo 2: Serilerin Düzeyde Birim Kök / Genişletilmiş Dickey Fuller (ADF) Test Sonuçları

\begin{tabular}{|l|c|c|c|}
\hline Değişken & \% $\mathbf{5}$ kritik değeri & Düzeyde t değeri & Olasılık değeri \\
\hline Aktif Karlılı̆̆ & -3.518090 & -3.179624 & 0.1020 \\
\hline Özsermaye Karlılı̆ı & -3.518090 & -2.502379 & 0.3256 \\
\hline Mevduat Faiz Oranı & -3.526609 & -3.323585 & 0.0770 \\
\hline
\end{tabular}


Tablo 2.' de görüldüğü gibi nedensellik ilişkisi için gerekli şartlardan olan serilerin aynı anda kendi düzeylerinde durağan olmaması şartı sağlanmıştır. Araştırmaya konu olan bütün seriler kendi düzeylerinde birim kök içermektedir. Bu noktadan sonra serilerin aynı anda durağan oldukları seviye belirlenecektir.

Eşbütünleşme testinin kullanılması için iki değişkenin aynı dereceden bütünleşik olması gerekmektedir. $y_{\mathrm{t}}$ ve $x_{\mathrm{t}}$ gibi durağan olmayan iki zaman serisi değişkeninin farklı dereceden bütünleşik olması, bu iki değişkenin eşbütünleşik olmadığını ve uzun dönemde birbirinden uzaklaşma eğiliminde olduğunu göstermektedir. Bu nedenle elde edilen ilişki sahte bir ilişki olacaktır (Aras ve Gülay,2011:351).

Tablo 3: Serilerin 1. Derece Farklarının Birim Kök / Genişletilmiş Dickey Fuller (ADF) Test Sonuçları

\begin{tabular}{|l|c|c|c|}
\hline Değişken & \% 5 kritik değeri & 1.farkında t değeri & Olasılık değeri \\
\hline Aktif Karlıı̆̆ı & -3.520787 & -6.151980 & 0.0000 \\
\hline Özsermaye Karlılı̆ıı & -3.520787 & -6.468825 & 0.0000 \\
\hline Mevduat Faiz Oranı & -3.529758 & -4.547150 & 0.0042 \\
\hline
\end{tabular}

Tablo 3.' de seriler incelendiğinde, bütün serilerin 1. dereceden farkı alındığında durağan hale geldiği görülmektedir. Olasılık değerleri, 0.05 den küçük çıkmıştır. Serilerin durağanlaşma düzeyi I(1) dir. Yani nedensellik ilişkisi için gerekli olan serilerin aynı derecede durağan olması şartı sağlanmıştır.

\subsection{Var (Vektör Otoregresif Model) ile Uygun Gecikmelerin Belirlenmesi Ve Johansen Eşbütünleşme Testi}

Değişkenlerimiz düzeyde durağan olmadığı için VAR Analizi ile uygun gecikme uzunluklarını belirleyerek analiz uygulanmıştır.

Tablo 4: VAR Analizi: Bilgi Kriterlerine Göre Uygun Gecikme Değerleri: Aktif Karlılığı Modeli

\begin{tabular}{|c|c|c|c|c|c|c|}
\hline Gecikme & LogL & LR & FPE & AIC & SC & HQ \\
\hline $\mathbf{0}$ & 85.34609 & NA & $4.22 \mathrm{e}-05$ & -4.397086 & $\mathbf{- 4 . 2 2 2 9 3 3}$ & -4.335689 \\
\hline $\mathbf{1}$ & 115.8298 & $54.37637^{*}$ & $1.01 \mathrm{e}-05^{*}$ & $-5.828639^{*}$ & $\mathbf{- 5 . 4 8 0 3 3 2 *}$ & $-5.705844^{*}$ \\
\hline $\mathbf{2}$ & 117.1337 & 2.184930 & $1.17 \mathrm{e}-05$ & -5.682904 & $\mathbf{- 5 . 1 6 0 4 4 4}$ & -5.498713 \\
\hline $\mathbf{3}$ & 120.5106 & 5.293398 & $1.22 \mathrm{e}-05$ & -5.649219 & $\mathbf{- 4 . 9 5 2 6 0 6}$ & -5.403630 \\
\hline $\mathbf{4}$ & 125.3463 & 7.057539 & $1.19 \mathrm{e}-05$ & -5.694393 & $\mathbf{- 4 . 8 2 3 6 2 7}$ & -5.387407 \\
\hline $\mathbf{5}$ & 126.4577 & 1.501941 & $1.42 \mathrm{e}-05$ & -5.538254 & $\mathbf{- 4 . 4 9 3 3 3 5}$ & -5.169871 \\
\hline $\mathbf{6}$ & 128.3219 & 2.317608 & $1.64 \mathrm{e}-05$ & -5.422804 & $\mathbf{- 4 . 2 0 3 7 3 1}$ & -4.993023 \\
\hline
\end{tabular}

* Seçilen gecikmeyi belirtmektedir. LR: LR Test İstatistiği, FPE: Son Tahmin Hatası, AIC: Akaike Bilgi Kriterleri, SC: Schwarz Bilgi Kriteri, HQ: Hannan - Quinn Bilgi Kriteri 
Tablo 5: VAR Analizi: Bilgi Kriterlerine Göre Uygun Gecikme Değerleri: Özsermaye Karlılığı Modeli

\begin{tabular}{|c|c|c|c|c|c|c|}
\hline Gecikme & LogL & LR & FPE & AIC & SC & HQ \\
\hline $\mathbf{0}$ & 6.535195 & NA & 0.002990 & -0.137038 & $\mathbf{0 . 0 3 7 1 1 6}$ & -0.075640 \\
\hline $\mathbf{1}$ & 39.32524 & 58.49034 & 0.000632 & -1.693256 & $\mathbf{- 1 . 3 4 4 9 4 9 *}$ & $-1.570462^{*}$ \\
\hline $\mathbf{2}$ & 40.25726 & 1.561775 & 0.000749 & -1.527420 & $\mathbf{- 1 . 0 0 4 9 6 0}$ & -1.343228 \\
\hline $\mathbf{3}$ & 46.32024 & $9.504123^{*}$ & 0.000675 & -1.638932 & $\mathbf{- 0 . 9 4 2 3 1 9}$ & -1.393343 \\
\hline $\mathbf{4}$ & 52.24856 & 8.652146 & $0.000617^{*}$ & $-1.74316^{*}$ & $\mathbf{- 0 . 8 7 2 3 9 9}$ & -1.436179 \\
\hline $\mathbf{5}$ & 52.57057 & 0.435153 & 0.000768 & -1.544355 & $\mathbf{- 0 . 4 9 9 4 3 6}$ & -1.175972 \\
\hline $\mathbf{6}$ & 53.92238 & 1.680622 & 0.000914 & -1.401210 & $\mathbf{- 0 . 1 8 2 1 3 7}$ & -0.971429 \\
\hline
\end{tabular}

* Seçilen gecikmeyi belirtmektedir. LR: LR Test İstatistiği, FPE: Son Tahmin Hatası, AIC: Akaike Bilgi Kriterleri, SC: Schwarz Bilgi Kriteri, HQ: Hannan - Quinn Bilgi Kriteri

Tablo 4. ve Tablo 5.'de verilen bilgi kriterlerinden Schwarz Bilgi Kriteri' ne göre hem aktif karlılığı ile hem de özsermaye karlılığı ile kurulan model için en uygun gecikme uzunluğu değeri 1'dir. Bulunan gecikme uzunluğunda otokorelasyon sorunu olup olmadığını da test etmek için LM Testi kullanılmıştır. Birinci gecikme için:

$\mathrm{H}_{0}=$ Birinci gecikmede otokorelasyon yoktur.

$\mathrm{H}_{1}=$ Birinci gecikmede otokorelasyon vardır.

Tablo 6: Otokorelasyon LM Testi Sonuçları

\begin{tabular}{|c|c|c|}
\hline Gecikmeler & LM İstatistiği & Olasılık Değeri \\
\hline $\mathbf{1}$ & $\mathbf{1 2 . 9 3 5 1 9}$ & $\mathbf{0 . 1 6 5 6}$ \\
\hline 2 & 11.78416 & 0.2258 \\
\hline 3 & 14.92934 & 0.0929 \\
\hline 4 & 7.746768 & 0.5599 \\
\hline 5 & 8.380636 & 0.4963 \\
\hline 6 & 13.36118 & 0.1469 \\
\hline 7 & 1.444586 & 0.9975 \\
\hline 8 & 12.09904 & 0.2078 \\
\hline 9 & 6.605131 & 0.6782 \\
\hline 10 & 3.661083 & 0.9323 \\
\hline 11 & 11.82442 & 0.2234 \\
\hline 12 & 12.52161 & 0.1855 \\
\hline
\end{tabular}

Tablo 6.'daki olasılık değerlerine baktığımızda, birinci gecikme için, $0.1656>0.05$ olduğundan sıfır hipotezi, kabul edilir. Birinci gecikme için otokorelasyon sorunu yoktur. Nedensellik analizine geçilebilir.

Kurulan iki modelin 1. gecikmede durağanlıklarını daha net görebilmek için ters köklerinin birim çemberdeki yerlerine bakılmıştır: 


\section{Şekil 2: Ters Köklerin Birim Çemberdeki Yeri}

a. Özsermaye Karlılığı İçin Ters Kökler:

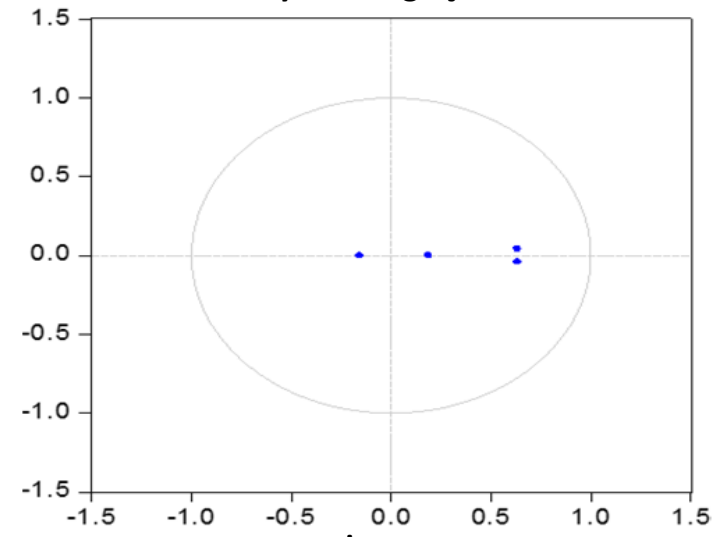

b. Aktif Karlılığı İçin Ters Kökler:

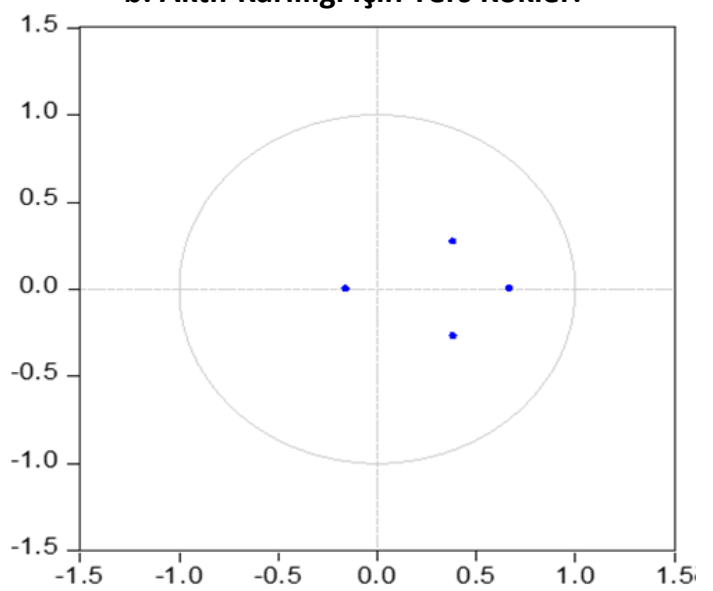

Şekil 2' den de anlaşılacağı gibi modellerimizdeki öz vektörler birim çemberin içinde yer almaktadır yani öz değerler 1'den küçük olup bir bütün olarak durağandır.

VAR modeli ile gecikme uzunluğu tespit edildikten sonra Johansen Eşbütünleşme Testi yapılmıştır. Bu testle eşbütünleşik vektör sayısı bulunacaktır. Eğer değişkenler arasında İz İstatistiği (Trace Statistics) ve Maksimum Öz Değer (Max-Eigenvalues) Testlerine göre koentegre vektör varsa değişkenler arasında eşbütünleşme ilişkisi vardır.

Eşbütünleşik vektörlerin sayısı, öz değerlerin kullanılarak log olabilirlik test istatistiğine dayanan iz istatistiği ve $r$ sayıda eş bütünleşme vektörünün $r+1$ sayıdaki alternatifi karşısında test edilmesine dayalı maksimum öz değer istatistiği (maximum eigenvalue statistics) ile bulunmaktadır. Bu doğrultuda da, iz istatistiği ile maksimum öz değer istatistiklerinin aldığı değerler kritik değerden büyük ise yokluk hipotezi (HO) reddedilmektedir (Johansen, 1988; Johansen ve Juselius, 1990). Eşbütünleşme ilişkisini sınama hipotezleri şu şekilde kurulur: 
$\mathrm{H}_{0}$ : Değişkenler arasında eşbütünleşme ilişkisi yoktur.

$\mathrm{H}_{1}$ : Değişkenler arasında eşbütünleşme ilişkisi vardır.

Tablo 7: Özsermaye Karlılığı İçin Johansen Eşbütünleşme Testi Sonuçları

\begin{tabular}{|c|c|c|c|}
\hline H0 Hipotezi & İz İstatistiği & \%5 Kritik Değer & Olasılık Değeri \\
\hline Hiç Yok* r=0 & 48.80186 & 25.87211 & 0.0000 \\
\hline En Çok 1 Tane & 6.886251 & 12.51798 & 0.3565 \\
\hline H0 Hipotezi & $\begin{array}{c}\text { Maksimum Özdeğer } \\
\text { İstatistiği }\end{array}$ & \%5 Kritik Değer & Olasılık Değeri \\
\hline Hiç Yok* r=0 & 41.91561 & 19.38704 & 0.0000 \\
\hline En çok 1 Tane $r \leq 1$ & 6.886251 & 12.51798 & 0.3565 \\
\hline
\end{tabular}

* \%5 e göre sıfır hipotezinin red edildiğini göstermektedir. $r$ : eşbütünleşik vektör sayısı

Tablo 8: Aktif Karlılığı için Johansen Eşbütünleşme Testi Sonuçları

\begin{tabular}{|l|l|l|l|}
\hline $\mathbf{H}_{\mathbf{0}}$ Hipotezi & İz İstatistiği & \%5 Kritik Değer & Olasılık Değeri \\
\hline Hiç Yok* r=0 & 51.21874 & 25.87211 & 0.0000 \\
\hline En Çok 1 Tane $r \leq 1$ & 10.04383 & 12.51798 & 0.1252 \\
\hline $\mathbf{H}_{\mathbf{0}}$ Hipotezi & $\begin{array}{c}\text { Maksimum Özdeğer } \\
\text { İstatistiği }\end{array}$ & \%5 Kritik Değer & Olasılık Değeri \\
\hline Hiç Yok* r=0 & 41.17492 & 19.38704 & 0.0000 \\
\hline En çok 1 Tane $r \leq 1$ & 10.04383 & 12.51798 & 0.1252 \\
\hline
\end{tabular}

* \%5 e göre sıfır hipotezinin red edildiğini göstermektedir. $r$ : eşbütünleşik vektör sayısı

Tablo 7. ve Tablo 8'e bakıldığında i̇z istatistiği değerlerimiz, kritik değerden yüksek çıkmıştır( $r=0$ için). Buna göre sıfır hipotezimiz reddedilmiştir. Bunun yanında, $r \leq 1$ hipotezi, aynı anlamlılık düzeyinde reddedilmemiştir. Karlılık değişkenleri ile Mevduat Faiz Oranları arasında Johansen Eşbütünleşme Testine göre 1'er eşbütünleşme denklemi bulunmuştur. Sonuç olarak eşbütünleşme denklemi bulunan değişkenler arasında uzun dönemli ilişki tespit edilmiştir.

\subsection{Vecm (Vector Error Correction Model) ile Granger Nedensellik Testi}

Değişkenler arasında uzun dönemli ilişkinin varlığını gösteren eşbütünleşme ilişkisinin (eşbütünleşme vektörünün) tespiti durumunda, nedensellik ilişkilerinin Hata Düzeltme Modeli (Vector Error Correction Model, VECM) ile analiz edilmesi gerekmektedir (Chimobi ve Igwe, 2010: 249 - 257).

Granger (1969) nedenselligi; “ $Y$ 'nin öngörüsü, $X$ 'in geçmiş değerleri kullanıldığında $X$ 'in geçmiş değerlerinin kullanılmadığı duruma göre daha başarılı ise $X$, $Y$ 'nin Granger nedenidir" şeklinde tanımlanmıştır. Bu ifadenin doğruluğu sınandıktan sonra ilişki $X^{\prime}$ den $Y^{\prime}$ ye doğru şeklinde ifade edilir. Yapılan analizler sonucunda; iki değişkenin birbirini gecikmeli olarak etkileyip etkilemedigi, eğer etkiliyorlarsa bu nedenselliğin tek yönlü 
( $X^{\prime}$ den $Y^{\prime}$ ye doğru veya $Y^{\prime}$ den $X^{\prime}$ 'e doğru) veya çift yönlü (hem $X^{\prime}$ den $Y^{\prime}$ ye doğru hem de $Y^{\prime}$ den $X^{\prime}$ e doğru) olduğu ortaya konulmaktadır. Nedenselliği sınama hipotezleri şu şekilde kurulur

$\mathrm{H}_{0}$ : $\mathrm{X}$ değişkeni, $\mathrm{Y}$ değişkeninin nedeni değildir.

$\mathrm{H}_{1}$ : $\mathrm{X}$ değişkeni, $\mathrm{Y}$ değişkeninin nedenidir.

Tablo 9: Granger Nedensellik Testi Sonuçları -1-

\begin{tabular}{|l|c|c|}
\hline Gecikme Sayısı:1 & \\
\hline H0 için: & F - İstatistiği & Olasılık Değeri \\
\hline Aktif Karlılığı, Mevduat Faiz Oranları'nın nedeni değildir. & $\mathbf{7 . 7 7 5 7 7 8}$ & $\mathbf{0 . 0 0 5 3 *}$ \\
\hline Mevduat Faiz Oranları, Aktif Karlılığı'nın nedeni değildir. & 0.080721 & 0.7763 \\
\hline
\end{tabular}

*Tablo 9'a baktığımızda “Aktif Karlılığı, Mevduat Faiz Oranları'nın nedeni değildir." Hipotezinin olasılık değeri, 0,05'den küçük çıktığı için hipotez reddedilir, yani; Aktif Karlılığı, Mevduat Faiz Oranları'nın nedenidir.

Tablo 10: Granger Nedensellik Testi Sonuçları -2-

\begin{tabular}{|c|c|c|}
\hline \multicolumn{3}{|l|}{ Gecikme Sayısı:1 } \\
\hline HO için: & F - İstatistiği & Olasılık Değeri \\
\hline $\begin{array}{l}\text { Özsermaye Karlılığı, Mevduat Faiz Oranları'nın nedeni } \\
\text { değildir. }\end{array}$ & 10.90315 & $0.0010^{*}$ \\
\hline $\begin{array}{l}\text { Mevduat Faiz Oranları, Özsermaye Karlılı̆̆ı'nın nedeni } \\
\text { değildir. }\end{array}$ & 0.096704 & 0.7558 \\
\hline
\end{tabular}

*Tablo 10'a baktığımızda “Özsermaye Karlılığı, Mevduat Faiz Oranları́nın nedeni değildir." Hipotezinin olasılık değeri, 0,05'den küçük çıktığı için hipotez reddedilir, yani; Özsermaye Karlılı̆̆, Mevduat Faiz Oranları'nın nedenidir.

Tablo 11: Granger Nedensellik Testi Sonuçları -3-

\begin{tabular}{|l|c|c|}
\hline Gecikme Sayısı:1 \\
\hline H0 için: & F - İstatistiği & Olasılık Değeri \\
\hline Aktif Karlılığı, Özsermaye Karlıı̆̆ı'nın nedeni değildir. & 2.067401 & $0.1505^{*}$ \\
\hline Özsermaye Karıı̆ı̆̆ı, Aktif Karlılığı'nın nedeni değildir. & 0.003989 & $0.9496^{*}$ \\
\hline
\end{tabular}

*Tablo 11.'de hiç bir nedensellik ilişkisi çıkmamıştır. Her iki hipotez için de olasılık değerleri, 0.05 'den büyük çıkmıştır. Hipotezler kabul edilir. Nedensellik yoktur. Bulunan nedensellik ilişkilerini aşağıdaki gibi gösterebiliriz: 
Şekil 3: Granger Nedensellik Testi Sonuçlarının Şema ile Gösterimi

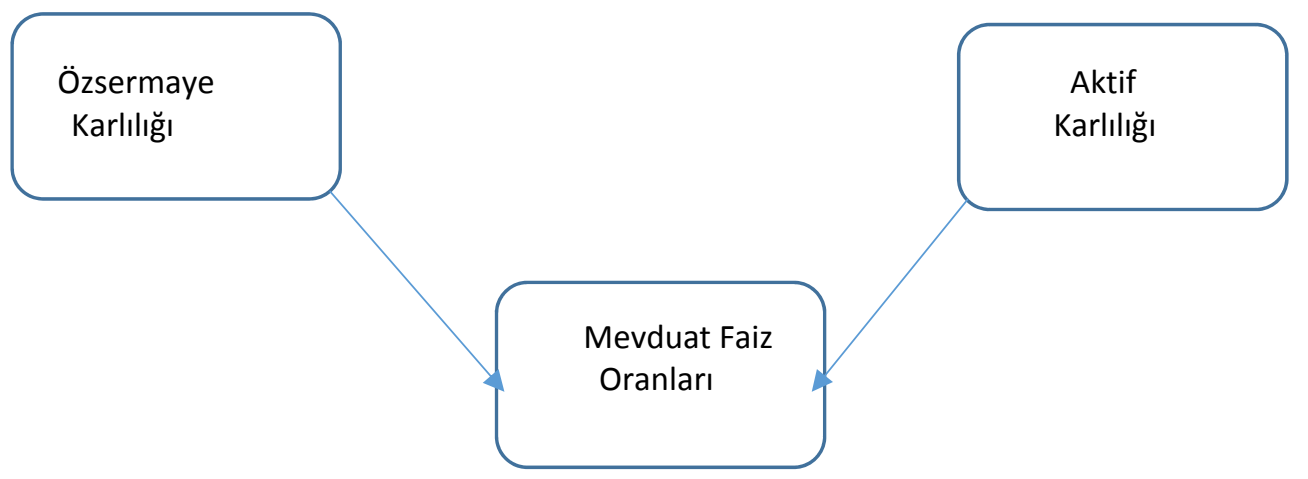

\section{SONUÇ}

Bu çalışmada, çeyrek dönemler itibariyle, 2003:1 - 2013:4 arasındaki dönemde Türkiye bankacılık sektörü mevduat bankalarının karlılık rasyoları ile mevduat faiz oranları arasındaki nedensellik ilişkisi araştırılmıştır. Bankaların karlılığı için, aktif karılı̆̆ı ve özsermaye karlılığı rasyoları kullanılmıştır. Seçilen dönemin 2008 krizini de içermesi nedeniyle, kriz kukla değişken yardımıyla çalışmaya dahil edilmiştir.

Karlılık serileri, mevsimsellik içerdiğinden, analize başlamadan önce bu durum giderilmiştir. Daha sonra serilerin durağanlığı, Genişletilmiş Dickey Fuller (ADF) testi ile kontrol edilmiştir. Birim kök testleri, tüm serilerin birinci farklarında durağanlığı sağladığını göstermiştir. Seriler aynı seviyede durağan olduklarından Johansen Eşbütünleşme Testi'ne geçilmiştir. Seriler için uygun gecikme uzunluğu, VAR Analizi ile Schwarz Bilgi Kriteri esas alınarak belirlenmiştir.

Eşbütünleşme testi sonuçlarına göre bankacılık sektöründe; aktif karlılığı, özsermaye karlılığı ve mevduat faiz oranları arasında uzun dönem denge ilişkisinin ve tek bir eşbütünleşme vektörünün mevcut olduğu bulunmuştur. Seriler eşbütünleşik olduğundan nedensellik testinin yapılması için vektör hata düzeltme modeli kullanılmıştır. Nedensellik testi sonuçlarına göre aktif karlılığından ve özsermaye karlılığından mevduat faiz oranlarına doğru tek yönlü ilişkiler tespit edilmiştir. Bunlar:

$>$ Aktif Karlılığı, Mevduat Faiz Oranları'nın nedenidir.

$>$ Özsermaye Karlılığı, Mevduat Faiz Oranları'nın nedenidir.

Mevduat faiz oranlarının yükselmesi maliyetleri artırdığı için bankacılık karlıı̆ı̆ını azaltır. Tasarruf miktarı, ekonomik ve konjonkturel şartlar, kredi talepleri, ekonomik istikrar ve beklentiler gibi mevduat faizlerini etkileyen çeşitli değişkenler vardır. Bunlardan biri de bankacılık karlılık oranlarıdır. Araştırmalardan elde edilen sonuçlara göre bankaların karlılığı, mevduat faizlerini belirlemede bir etkendir.

Bunun yanında; bankalar, karlılık durumuna göre mevduata ödediği faiz oranlarını düşürme imkanına sahiptir. 
Dolayısıyla daha yüksek karlılık oranlarına sahip olan bankalar daha düşük maliyetle mevduat toplayabilirler. Bu da yine bankaların karlıı̆ına olumlu katkı sağlar.

Bu çalışma, farklı faktörlerin etkisi gözetilerek de genişletilebilir. Bankalara ait hisse senedi getirilerini etkilediği düşünülen makro ekonomik değişkenler olarak BiST 100 endeksi, döviz kuru, kapasite kullanım oranı, hazine bonosu faiz oranı, para arzı, sanayi üretim endeksi, altın fiyatları ve cari işlemler dengesi modele dahil edilebilir. Böylece duruma çok yönlü bakılarak farklı değerlendirmeler de yapılabilir.

\section{KAYNAKLAR}

Albayrak, Y. E. ve Erkut, H. (2005), Banka Performans Değerlendirmede Analitik Hiyerarşi Süreç Yaklaşımı, iTÜ Dergisi/d, Mühendislik Serisi, 4(6), ss. 47-58.

Aras, S. ve Gülay E. (2011), Bulanık Mantık Tabanlı Ekonometrik Modelleme: Para Talebi - Türkiye Örneği. Ege Akademik Bakış Dergisi, 11(3), ss. 349 - 359.

Atasoy, H. (2007), Türk Bankacılık Sektöründe Gelir-Gider Analizi ve Karlılı Performansının Belirleyicileri, Uzmanlık Yeterlilik Tezi, TCMB Bankacılık ve Finansal Kuruluşlar Genel Müdürlüğü, Ankara.

Chimobi, O. P. and Igwe, O. L. (2010), Financial Innovations and the Stability of Money Demand in Nigeria. Banking and Finance Letters, Vol. 2, No. 1, pp. 249-257.

Çerçi, G. (2011), Bankalarda Karlılık Analizi: Türk Bankacılık Sektörü Üzerine Bir Uygulama, Basılmamış Yüksek Lisans Tezi, Çukurova Üniversitesi, Sosyal Bilimler Enstitüsü.

Çoban, O. ve Şahin, S. (2011), Türkiye'de Para Politikalarının Bankaların Karlılığı Üzerine Etkisi, S. Ü., i.i.B.F., Sosyal ve Ekonomik Araştırmalar Dergisi, 16(22), ss. 335-350.

Dietrich, A., Wanzenried. G. (2011), Determinants of bank profitability before and during the crisis: Evidence from Switzerland, Journal of International Financial Markets, Institutions and Money, 21(3), July 2011, pp. 307327.

Eğilmez, M. (2013), Merkez Bankası Faizleri ve Faiz Politikası, http://www.mahfiegilmez.com/ 2013/12/merkezbankas-faizleri-ve-faiz-politikas.html, (16.02.2015)

Granger, C. W. J. (1969), Investigating Causal Relations by Econometric Models and Cross-Spectral Methods. Econometrica, Vol. 37, No. 3, pp. 424-438.

Greuning, H. V. ve Bratanovic (2000), Analyzing banking risk, World Bank Washington D.C.

Guru, B. K., Staunton, J., Balashanmugam, B. (2002), Determinants of Commercial Bank Profitability in Malaysia, Working Paper, Multimedia University

Gündoğdu, F. ve Aksu, H. (2011), Mevduat Bankacılığında Karlılık ve Makroekonomik Değişkenler iliş̧kisi: Türkiye Üzerine Bir Uygulama, Atatürk Üniversitesi, i.i.B.F. Dergisi, 10. Ekonometri ve istatistik Sempozyumu Özel Sayısı, ss. $243-270$.

İşcan, E. ve Oransay, G. (2011), Banka Karlılıklarının Banka Özellikli, Sektör Özellikli ve Makroekonomik Belirleyicileri: Türk Bankacılık Sektöründe 2002-2010 Dönemi, Paper presented at Econ Anadolu 2011, Anadolu International Conference in Economics II, June 15-17, 2011, Eskişehir-Turkey.

Jiang, G. vd. (2003). The Profitability of Banking Sector in Hong Kong, Hong Kong Monetary Authority Quarterly Bulletin, pp. 5-14.

Johansen, S. (1988), Statistical Analysis of Cointegrating Vectors. Journal of Economic Dynamics and Control, 12, pp. 231-254. 
Johansen, S. ve Juselius, K. (1990), Maximum Likelihood Estimation and Inferences on Co-Integration with Application to the Demand for Money. Oxford Bulletin of Economics and Statistics, 52(2), pp. 169-210.

Kaya, T.Y. (2002), Türk Bankacılık Sektöründe Kârlıığın Belirleyicileri:1997-2000, BDDK MSPD Çalışma Raporları, 2002/1

Kaya, Y. T. ve Doğan, E., (2005), Dezenflasyon Sürecinde Türk Bankacılık Sektöründe Etkinliğin Gelişimi, ARD Çalışma Raporları, BDDK Yayınları, 2005 (10), ss. 1-16.

Kibritçi Artar, O. ve Atılgan Sarıdoğan, A. (2012), Küresel Finans Krizinin Türkiye'de Bankacılık Sektörü Mali Yapısına Etkileri, Marmara Sosyal Araştırmalar Dergisi, 2012 (2), ss. 1-17.

Koşan, N. i. (2009), Türkiye'de Cari Açığı Etkileyen Faktörlerin Ekonometrik Analizi, YayınlanmamışYüksek Lisans Tezi, Marmara Üniversitesi Sosyal Bilimler Enstitüsü.

Kutlar, Aziz (2005), Uygulamalı Ekonometri, (2. Baskı), Ankara: Nobel Yayın Dağııım.

Molyneux, P. ve Thornton, J. (1992), Determinants of European Bank Profitability: A Note, Journal of Banking and Finance, 16(6), pp. 1173-1178.

Saldanlı, A. (2013), Türk Bankacılık Sektörüne Genel Bakış: 2000-2012 Yılları Arası Rasyo Analizi, Dicle Üniversitesi, Sosyal Bilimler Enstitüsü Dergisi, Kasım, 5(10), ss. 40-52.

Sarıtaş, H. ve Saray, C. (2012), Türk Bankacılık Sektörünün Karlılık ve Performansının Analizi, Pamukkale Üniversitesi, Sosyal Bilimler Enstitüsü Dergisi, Sayı 11, ss. 23-37.

Tarkoçin, C., ve Yekeler, A. (2010), Faiz Oranlarının Küresel Kriz Döneminde Değişimi ve Bankacılık SektörüÜzerindeki Etkileri, Türkiye Ekonomi Kurumu Uluslararası Ekonomi Konferansı, 1-3 Eylül 2010, Girne, KKTC.

Taşkın, F. D. (2011), Türkiye'de Ticari Bankaların Performansını Etkileyen Faktörler, Ege Akademik Bakış, 11(2), Nisan, ss. $289-298$.

Uludağ, B. K. Ve Gökmen, H. (2010), Türk Bankacılık Sektöründe Karlılığın Dinamik Yaklaşımla Test Edilmesi, 14. Ulusal Finans Sempozyumu, S.Ü. I.I..B.F., 3-6 Kasım, Konya, ss. 135-152.

http://www.ekodialog.com/Konular/faiz_politikasi.html, (01.06.2014).

http://evds.tcmb.gov.tr/(01.06.2014).

http://www.tbb.org.tr/(01.06.2014).

http://www.turcomoney.com/turk-bankacilik-sektoru.html, (01.06.2014). 